\title{
NMDA Receptor-Mediated $\mathrm{Na}^{+}$Signals in Spines and Dendrites
}

\author{
Christine R. Rose and Arthur Konnerth \\ Institut für Physiologie, Ludwig-Maximilians-Universität München, D-80802 München, Germany
}

\begin{abstract}
Spines and dendrites of central neurons represent an important site of synaptic signaling and integration. Here we identify a new, synaptically mediated spine signal with unique properties. Using two-photon $\mathrm{Na}^{+}$imaging, we show that suprathreshold synaptic stimulation leads to transient increases in $\mathrm{Na}^{+}$concentration in postsynaptic spines and their adjacent dendrites. This local signal is restricted to a dendritic domain near the site of synaptic input. In presumed active spines within this domain, the $\mathrm{Na}^{+}$level increases by 30-40 mM even during short bursts of synaptic stimulation. During a long-term potentiation induction protocol $(100 \mathrm{~Hz}, 1 \mathrm{sec})$, the $\mathrm{Na}^{+}$level in the active spines
\end{abstract}

Dendritic spines represent the major postsynaptic input site for excitatory transmission in the brain (Harris and Kater, 1994). Despite this central feature, their role in information processing is still not completely understood (Koch and Zador, 1993; Harris, 1999; Segal et al., 2000). So far, two classes of spine signals have been observed during synaptic transmission. One class of synaptically induced spine signals is changes in the membrane potential. These can be recorded only at distant sites, because spines themselves are inaccessible to direct electrical measurements. In recent years, the development of high-resolution imaging techniques has enabled the detection of a second spine signal (Denk et al., 1996) that is composed of transient elevations in the intracellular $\mathrm{Ca}^{2+}$ concentration (Eilers and Konnerth, 1997; Yuste et al., 2000).

When the postsynaptic membrane is sufficiently depolarized, influx of $\mathrm{Ca}^{2+}$ into spines can be mediated through NMDA receptors and induce activity-dependent changes in synaptic properties such as long-term potentiation (LTP) or long-term depression (LTD) (Malenka, 1994). Close to the resting potential, another type of glutamate receptor, the so-called AMPA receptor, which in general is much less permeable to $\mathrm{Ca}^{2+}$, is activated.

The major current carrier for both glutamate-gated channels, however, is $\mathrm{Na}^{+}$. Therefore, excitatory synaptic transmission is also expected to significantly alter the postsynaptic $\mathrm{Na}^{+}$concentration. Indeed, dendritic $\mathrm{Na}^{+}$accumulation induced by synaptic stimulation was observed in cerebellar Purkinje and hippocampal CA1 neurons (Lasser-Ross and Ross, 1992; Miyakawa et al., 1992; Callaway and Ross, 1997). In these studies, however, no spatial resolution of spines was obtained, and an analysis of the spatial distribution of the signals could not be performed. Moreover, no

Received March 2, 2001; revised April 3, 2001; accepted April 5, 2001.

This study was supported by the Deutsche Forschungsgemeinschaft and the Bundesministerium für Bildung und Forschung.

Correspondence should be addressed to Christine R. Rose, Institut für Physiologie, Ludwig-Maximilians-Universität München, Biedersteiner Strasse 29, D-80802 München, Germany. E-mail: rose@Irz.uni-muenchen.de.

Copyright (C) 2001 Society for Neuroscience $\quad 0270-6474 / 01 / 214207-\bullet \$ 15.00 / 0$ reaches peak amplitudes of $\sim 100 \mathrm{~mm}$. We find that the $\mathrm{Na}^{+}$ transients are mainly mediated by $\mathrm{Na}^{+}$entry through NMDA receptor channels and are detected during the coincident occurrence of synaptic potentials and backpropagating action potentials. The large amplitudes of the $\mathrm{Na}^{+}$transients and their location on dendritic spines suggest that this signal is an important determinant of electrical and biochemical spine characteristics.

Key words: dendrite; spine; two-photon imaging; sodium; NMDA; coincidence detection; hippocampus estimate concerning the actual amplitude of the $\mathrm{Na}^{+}$changes was made.

A more detailed knowledge of postsynaptic $\mathrm{Na}^{+}$transients is desirable because changes in the electrochemical $\mathrm{Na}^{+}$gradient will alter the reversal potential of excitatory synaptic currents and $\mathrm{Na}^{+}$-dependent transporters such as $\mathrm{Na}^{+} / \mathrm{Ca}^{2+}$-exchange (Blaustein and Lederer, 1999) and therefore could significantly influence synaptic function. Moreover, several studies indicated that $\mathrm{Na}^{+}$might play a role in activity-dependent synaptic plasticity. An earlier report showed that $\mathrm{Na}^{+}$influx through AMPA receptor channels is required for the induction of LTD in cerebellar Purkinje neurons (Linden et al., 1993). In hippocampal neurons, intracellular $\mathrm{Na}^{+}$increases have been proposed to increase the open probability of NMDA receptors via activation of the protein tyrosine kinase Src and thus might control the gain of excitatory transmission (Yu and Salter, 1998).

In the present study we used two-photon $\mathrm{Na}^{+}$imaging in combination with whole-cell patch-clamp recordings (Rose et al., 1999) to measure action potential (AP)-induced and synaptically induced $\mathrm{Na}^{+}$signals in spines and dendrites in a hippocampal slice preparation. This technique is particularly well suited for measurement of $\mathrm{Na}^{+}$transients in small cellular compartments because excitation is limited to the focal plane, allowing imaging in the intact, scattering tissue (Denk et al., 1990). Our results demonstrate the presence of local postsynaptic $\mathrm{Na}^{+}$transients in spines and dendrites. We provide evidence that $\mathrm{Na}^{+}$transients are mediated mainly by $\mathrm{Na}^{+}$entry through NMDA receptorgated channels.

\section{MATERIALS AND METHODS}

Tissue preparation and patch-clamp recordings. CD-1 mice (Charles River; 3-5 weeks old) were anesthetized and decapitated. Transverse hippocampal slices $(300 \mu \mathrm{m})$ were prepared as described previously, and standard techniques were used for somatic whole-cell patch-clamp recordings (Edwards et al., 1989). CA1 pyramidal cells were generally held at membrane potentials of -60 to $-65 \mathrm{mV}$; granule cells of the dentate gyrus were held at -75 to $-80 \mathrm{mV}$. Because of better space-clamp characteristics, voltage-clamp experiments were exclusively performed on granule cells. The intracellular solution for patch-clamp experiments 
contained (in mM): $120 \mathrm{~K}^{+}$-gluconate, $10 \mathrm{HEPES}, 32 \mathrm{KCl}, 4 \mathrm{NaCl}, 0.16$ EGTA, 4 Mg-ATP, 0.4 NaGTP, 2 tetraammonium salt of sodium-binding benzofuran isophthalate (SBFI) (Molecular Probes, Eugene, OR) and was titrated with $\mathrm{KOH}$ to a $\mathrm{pH}$ of 7.3. During experiments, slices were perfused with physiological saline containing (in $\mathrm{mM}$ ): $125 \mathrm{NaCl}, 4 \mathrm{KCl}$, $1.25 \mathrm{NaH}_{2} \mathrm{PO}_{4}, 26 \mathrm{NaHCO}_{3}, 2 \mathrm{CaCl}_{2}, 1 \mathrm{MgCl}_{2}, 20$ glucose, continuously bubbled with $95 \% \mathrm{O}_{2} / 5 \% \mathrm{CO}_{2}$ resulting in a $\mathrm{pH}$ of 7.4. GABAergic transmission was blocked by using $10 \mu \mathrm{M}$ bicuculline methiodide. Experiments were performed at room temperature $\left(22-24^{\circ} \mathrm{C}\right)$. To mimic burst activity of CA3 neurons, Schaffer collaterals were electrically stimulated by five $2 \mathrm{msec}$ square pulses delivered at $50 \mathrm{~Hz}$ via a thin glass pipette filled with saline. To activate granule cells, the stimulation electrode was placed in the molecular layer of the dentate gyrus. The stimulation pipettes were placed at a distance of $10-15 \mu \mathrm{m}$ from the dendrites. Stimulation strength was set just below action potential firing threshold for subthreshold stimulation and just above firing threshold for suprathreshold stimulation.

$\mathrm{Na}^{+}$imaging. Imaging was performed using a custom-built two-photon laser-scanning microscope based on a mode-locked Ti:sapphire laser system operated at $790 \mathrm{~nm}$ center wavelength, $80 \mathrm{MHz}$ pulse repeat, $<100$ fsec pulse width (Tsunami and Millenia, Spectra Physics, Mountain View, CA), and a laser-scanning system (MRC 1024, Bio-Rad, Herts, UK) mounted on an upright microscope (BX50WI, Olympus, Tokyo, Japan) equipped with $20 \times 0.5 \mathrm{NA}$ and $60 \times 0.9$ NA water immersion objectives (Olympus). Neurons were filled with SBFI via the patch pipette for at least $45 \mathrm{~min}$ before the recordings were started. Images were acquired at $4-8 \mathrm{~Hz}$. Background-corrected images were analyzed off-line with a custom-written routine in LabView (National Instruments, Austin, TX). In situ calibration of SBFI fluorescence with $\mathrm{Na}^{+}$ionophores enabled the determination of the actual magnitude of the $\mathrm{Na}^{+}$ changes (Rose and Ransom, 1997; Rose et al., 1999). Unless specified otherwise, data are expressed as means \pm SEM, and data traces shown are averages of one to three consecutive trials. Data were statistically analyzed by a Student's $t$ test (significance level, $p<0.005$ ).

\section{RESULTS}

By combining whole-cell patch-clamp recordings with two-photon laser-scanning microscopy (Denk et al., 1990), we analyzed synaptically and action potential-induced $\mathrm{Na}^{+}$changes in apical dendrites and spines of neurons in hippocampal slice preparations of 3- to 5-week-old mice. Common patterns of activity in the hippocampus are bursts of two to seven action potentials (Otto et al., 1991; Lisman, 1997). To induce such burst activity in CA1 pyramidal neurons, Schaffer collaterals were electrically stimulated by trains of five pulses delivered at $50 \mathrm{~Hz}$. Granule cells of the dentate gyrus were similarly activated by placing the stimulation electrode in the molecular layer of the dentate gyrus.

\section{Spatial profile of $\mathrm{Na}^{+}$transients}

Suprathreshold synaptic activation leads to widespread elevations of $\mathrm{Ca}^{2+}$ throughout the dendritic tree because of backpropagation of action potentials and the resulting opening of voltagegated $\mathrm{Ca}^{2+}$ channels (Jaffe et al., 1992; Markram et al., 1995; Spruston et al., 1995b; Yuste and Denk, 1995). Because apical dendrites of CA1 pyramidal neurons also express voltage-gated $\mathrm{Na}^{+}$channels (Stuart et al., 1997), we first determined the spatial profile of synaptically induced dendritic $\mathrm{Na}^{+}$accumulations. Figure 1 shows intracellular $\mathrm{Na}^{+}$transients induced by suprathreshold synaptic stimulation (five stimuli resulting in four to five postsynaptic APs) (Fig. 1b) along different regions of a secondary apical dendrite of a CA1 pyramidal neuron.

When the stimulation electrode was placed in close proximity to the dendrite $(10-15 \mu \mathrm{m})$ (Fig. $1 a)$, synaptically induced $\mathrm{Na}^{+}$ transients were maximal in the dendritic region, which was near $(10-50 \mu \mathrm{m})$ the pipette (Fig. 1c). Synaptic activation of the postsynaptic dendrite is expected from $\mathrm{Ca}^{2+}$ imaging measurements that were performed under similar conditions (Kovalchuk et al., 2000). Furthermore, to assure that these changes were not
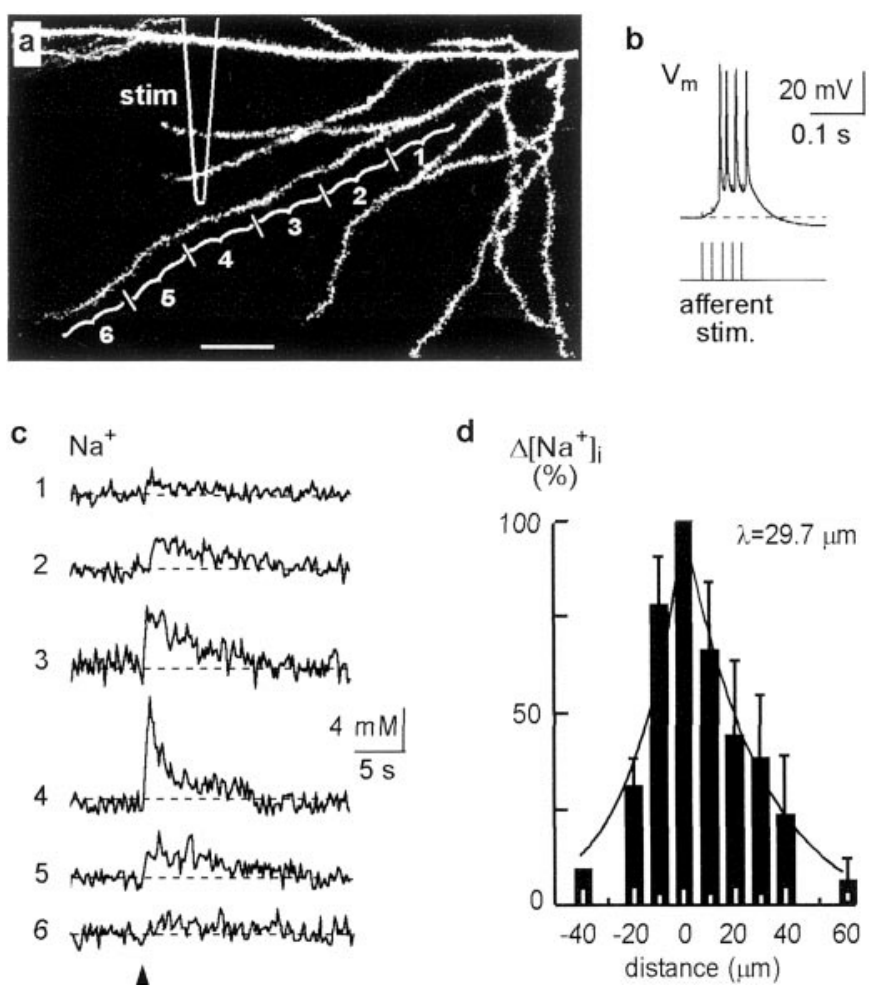

Figure 1. Local dendritic $\mathrm{Na}^{+}$transients induced by synaptic stimulation. $a$, Reconstruction of a stack of 27 optical sections taken at $1.5 \mu \mathrm{m}$ intervals through part of a CA1 pyramidal neuron filled with $2 \mathrm{mM} \mathrm{SBFI}$ (objective: $60 \times 0.9 \mathrm{NA}$ ). The brackets numbered 1-6 indicate the dendritic regions from which fluorescence measurements in $c$ were obtained. The position of the stimulation electrode is indicated schematically. Scale bar, $20 \mu \mathrm{m}$. Distance of region 1 from the cell body is $120 \mu \mathrm{m}$. $b$, Membrane potential change at the soma $\left(V_{\mathrm{m}}\right)$ induced by five afferent stimuli at $50 \mathrm{~Hz}$ as indicated in the bottom trace. $c, \mathrm{Na}^{+}$transients in the dendritic regions 1-6 caused by suprathreshold afferent stimulation as in $b$. $\mathrm{Na}^{+}$transients were maximal in region 4 , which was closest to the stimulation pipette. $\mathrm{Na}^{+}$changes in the different regions were measured successively, because the focal plane did not include the complete dendrite. $d$, Bar graph summarizing the normalized amplitude of activityinduced dendritic $\mathrm{Na}^{+}$transients (mean $\pm \mathrm{SEM}$ ). The bars represent 4-16 observations taken from 16 cells. The bar at $-40 \mu \mathrm{m}$ summarizes data from two experiments. The amplitude of $\mathrm{Na}^{+}$transients decayed monoexponentially with increasing distance from the region of maximal response with a length constant $(\lambda)$ of $\sim 30 \mu \mathrm{m}$. The arrowhead in $c$ indicates the time of synaptic stimulation.

caused by direct activation of voltage-sensitive channels by the stimulation current, we applied the postsynaptic blockers 6-cyano-7-nitroqionoxaline-2,3-dione (CNQX; $10 \mu \mathrm{M})$ and DL-2amino-5-phosphovaleric acid (APV; $100 \mu \mathrm{M})$. During perfusion with these drugs, both membrane potential changes and $\mathrm{Na}^{+}$ transients were abolished, indicating that they were indeed caused by synaptic activity ( $n=4$; data not shown).

The amplitudes of $\mathrm{Na}^{+}$transients reached $\sim 10 \mathrm{~mm}$ in the experiment depicted in Figure 1 [for calibration procedures, see Rose et al. (1999)]. This region of maximal response extended across a dendritic length of 20-30 $\mu \mathrm{m}$. With increasing distance from the region of maximal response, the site of synaptic input, the amplitude of the $\mathrm{Na}^{+}$transients decayed in a monoexponential fashion with a length constant $\left(\lambda_{\mathrm{Na}^{+}}\right)$of $\sim 30 \mu \mathrm{m}(n=16$ cells) (Fig. 1d). In other dendritic branches, small $\mathrm{Na}^{+}$signals just above the detection threshold $(\sim 1-2 \mathrm{~mm})$ were observed. This is in line with an earlier study in which we showed that short bursts of backpropagating action potentials cause only minor changes in 

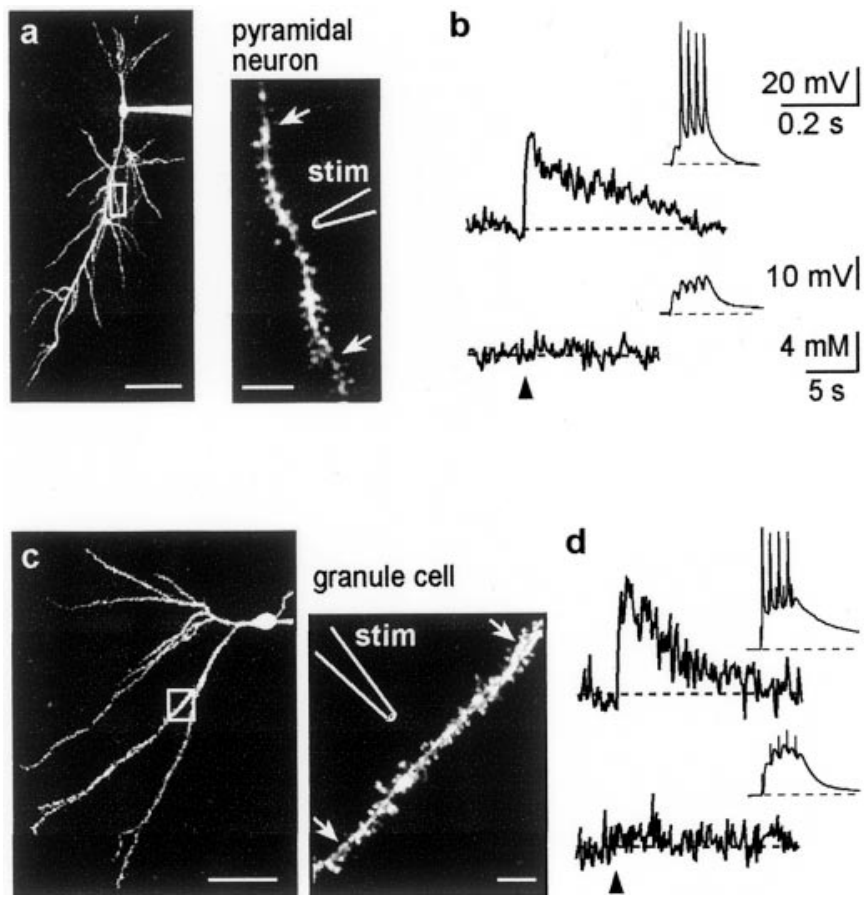

Figure 2. $\mathrm{Na}^{+}$transients require suprathreshold stimulation. $a$, Left, Reconstruction of a stack of 24 optical sections taken at $5 \mu \mathrm{m}$ intervals through an SBFI-filled CA1 pyramidal cell. The white box indicates the area enlarged in the right panel. Right, Spiny dendrite from the same cell taken at higher resolution (15 stacks at $0.4 \mu \mathrm{m})$. The position of the stimulation electrode is indicated schematically. The arrows indicate the dendritic region from which measurements in $b$ were obtained. $b$, Suprathreshold synaptic stimulation (top traces) induced a prominent $\mathrm{Na}^{+}$transient in the dendrite, whereas subthreshold stimulation (bottom traces) did not result in a measurable $\mathrm{Na}^{+}$increase. $c$, Left, Stack of 20 optical sections (3.5 $\mu \mathrm{m}$ intervals) through a granule cell of the dentate gyrus filled with SBFI. The white box indicates the area enlarged on the right. Right, Spiny dendrite from the same cell (15 stacks at $0.7 \mu \mathrm{m})$; the stimulation electrode is indicated schematically. The arrows indicate the dendritic region from which measurements in $d$ were obtained. $d$, Suprathreshold stimulation evoked a $\mathrm{Na}^{+}$transient in the dendrite (top traces). Subthreshold stimulation, in contrast, did not result in a $\mathrm{Na}^{+}$transient (bottom traces). Scale bars: $a, 50 \mu \mathrm{m}$, inset, $5 \mu \mathrm{m} ; c, 20 \mu \mathrm{m}$, inset, $5 \mu \mathrm{m}$. Arrowheads in $b$ and $d$ indicate the time of synaptic stimulation. Calibration for $d$ is shown in $b$.

$\mathrm{Na}^{+}$concentration throughout the dendritic tree (Rose et al., 1999).

These results demonstrate that suprathreshold stimulation leads to local $\mathrm{Na}^{+}$transients that occur in dendritic domains near the site of synaptic activation. In all subsequent experiments, the analysis of $\mathrm{Na}^{+}$transients was confined to dendritic regions and their adjacent spines $\sim 15-20 \mu \mathrm{m}$ proximal and distal to the position of the stimulation pipette.

\section{$\mathrm{Na}^{+}$transients require suprathreshold stimulation}

Whereas suprathreshold activation has been reported to induce widespread dendritic $\mathrm{Ca}^{2+}$ transients (Markram et al., 1995; Yuste and Denk, 1995; Jaffe and Brown, 1997), subthreshold stimulation can elicit local dendritic $\mathrm{Ca}^{2+}$ signals that are confined to the site of activation (Markram and Sakmann, 1994; Eilers et al., 1995; Yuste and Denk, 1995; Kovalchuk et al., 2000). Synaptically induced dendritic $\mathrm{Na}^{+}$signals, however, could be detected only with suprathreshold synaptic stimulation (Fig. 2). When the stimulation strength was set just below the threshold for action potential firing, no measurable change in the $\mathrm{Na}^{+}$level was observed. Increasing the stimulation strength just above firing threshold, in contrast, resulted in prominent $\mathrm{Na}^{+}$transients in the apical dendrites of CA1 pyramidal cells $(n=25)$ (Fig. $2 a, b)$. The amplitudes of these $\mathrm{Na}^{+}$transients were dependent on the number of suprathreshold stimuli. Five stimuli (four to five action potentials) resulted in dendritic $\mathrm{Na}^{+}$transients that amounted to $13.4 \pm 1.1 \mathrm{~mm}(n=33$ cells) (Fig. $3 e)$ and three stimuli (two to three action potentials) evoked $\mathrm{Na}^{+}$transients of $8.6 \pm 1.7 \mathrm{~mm}$ ( $n=6$ cells; data not shown), whereas a single stimulus resulting in one action potential evoked a $\mathrm{Na}^{+}$rise close to the detection threshold $(4.3 \pm 1.0 ; n=7$ cells; data not shown).

Activity-induced $\mathrm{Na}^{+}$transients were not restricted to CA1 pyramidal cells but could also be evoked in granule cells of the dentate gyrus. As observed for CA1 pyramidal cells, measurable dendritic $\mathrm{Na}^{+}$transients were elicited only with suprathreshold synaptic stimulation $\left(\Delta \mathrm{Na}^{+}=11.6 \pm 1.5 \mathrm{~mm} ; n=8\right)($ Fig. $2 c, d)$.

\section{$\mathrm{Na}^{+}$transients in spines}

We next attempted to identify "active" spines (Denk et al., 1995; Yuste and Denk, 1995), that is, the spines directly activated during synaptic stimulation. As reported above for dendritic $\mathrm{Na}^{+}$ transients, synaptically induced $\mathrm{Na}^{+}$signals in spines were observed only with suprathreshold stimulation (the signal-to-noise ratio allowed reliable detection of $\mathrm{Na}^{+}$transients in single spines of $\sim 5 \mathrm{~mm}$ ). Unambiguous identification of active spines was difficult because suprathreshold stimulation produced $\mathrm{Na}^{+}$transients in all spines of the active domain. The plotting of a distribution histogram of peak $\mathrm{Na}^{+}$transients of all spines, however, revealed a bimodal distribution of response amplitudes, clearly indicating the presence of two classes of spines (Fig. $3 d$ ).

In the first class of spines ( $75 \%$ of 152 spines; $n=18$ cells), the $\mathrm{Na}^{+}$level rose by $14.6 \pm 1.8 \mathrm{~mm}$ (stimulation parameters set to five pulses at $50 \mathrm{~Hz}$ ) (Fig. 3b), a level that was only slightly higher than that of the dendrites $(\sim 13 \mathrm{~mm}$; see above and Fig. $3 c-e)$. Moreover, the decay of the $\mathrm{Na}^{+}$transients in these spines and in dendritic regions was monoexponential with time constants of $8.8 \pm 1.6 \mathrm{sec}$ (spines) and $9.0 \pm 2.1 \mathrm{sec}$ (dendrites; $n=16$ cells) (Fig. $3 c, e)$. In contrast, in the second class of spines ( $25 \%$ of 152 ; $n=18$ cells), activity-induced $\mathrm{Na}^{+}$transients were two to three times higher than those of the adjacent dendrite, reaching up to 35-40 mM (mean $35.7 \pm 4 \mathrm{~mm}$ ) (Fig. 3). Recovery followed a biexponential decay with a fast time constant $\left(\tau_{\mathrm{f}}\right)$ of $1.6 \pm 0.5 \mathrm{sec}$ and a slow time constant $\left(\tau_{\mathrm{s}}\right)$ that was very similar to the dendritic decay constant $(8.5 \pm 1.9 \mathrm{sec})$ (Fig. $3 e$ ). We assume, therefore, that these spines were the sites of synaptic input and thus the sites of synaptic $\mathrm{Na}^{+}$influx (active spines). In the other class of spines, in which the amplitude and the time course of $\mathrm{Na}^{+}$transients corresponded to that of the dendrites, the $\mathrm{Na}^{+}$signals were probably caused by diffusion of free and SBFI-bound $\mathrm{Na}^{+}$ions from their site of entry ("passive" spines).

Because of the relatively low image sampling frequency (4-8 $\mathrm{Hz}$ ) and the required additional binning to improve the signalto-noise ratio of the fluorescence signals from single spines, our measurements very likely underestimated the peak amplitude of the $\mathrm{Na}^{+}$increase in active spines. Earlier calculations estimated that a single presynaptic action potential results in a rapid $\mathrm{Na}^{+}$ increase by $\sim 30 \mathrm{~mm}$ in postsynaptic spines during excitatory transmission (Sejnowski and Qian, 1992). For the same reasons, $\tau_{\mathrm{f}}$, which most likely represents both active $\mathrm{Na}^{+}$extrusion and diff usion of $\mathrm{Na}^{+}$from spines to dendrites (Majewska et al., 2000), is probably overestimated. Furthermore, although SBFI concentration was low $(2 \mathrm{~mm})$ in comparison with the observed $\mathrm{Na}^{+}$ 


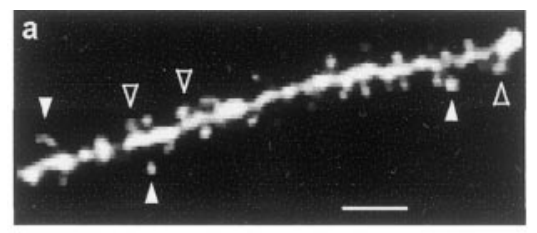

b

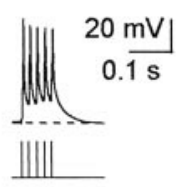

c

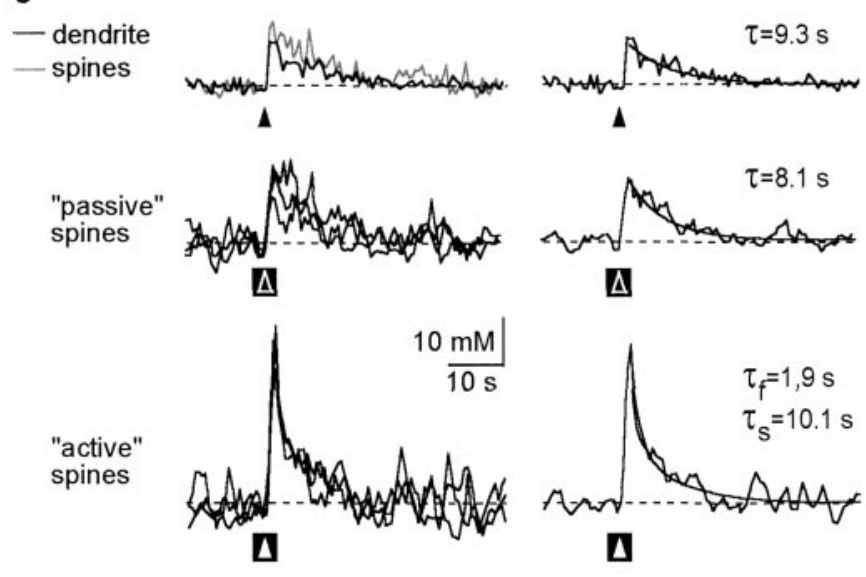

d
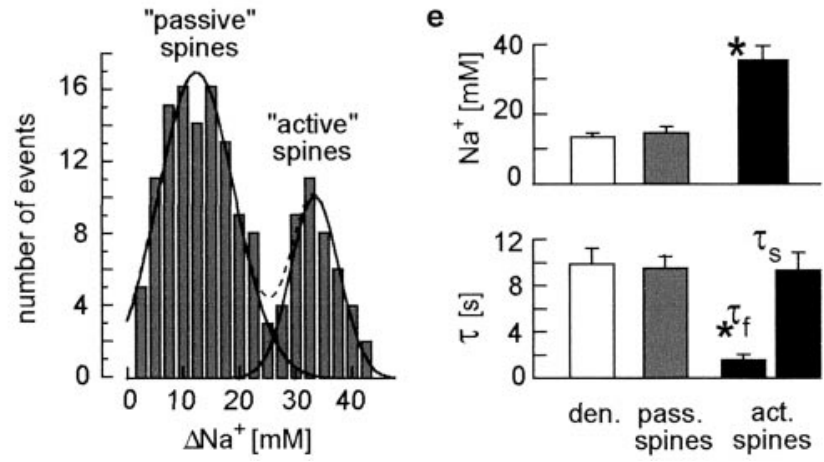

Figure 3. Synaptically induced $\mathrm{Na}^{+}$transients in spines. $a$, Image of the spiny dendrite of a CA1 pyramidal cell chosen for the experiment depicted in $b$ and $c$. Closed arrowheads indicate active spines; open arrowheads indicate passive spines from which measurements in $c$ were taken. Scale bar: $5 \mu \mathrm{m}$; distance from the cell body: $140 \mu \mathrm{m}$. $b$, Suprathreshold stimulation ( 5 afferent stimuli at $50 \mathrm{~Hz}$ ) induced five APs as measured at the soma. c, Left, Average activity-induced $\mathrm{Na}^{+}$transient in spines (average of 19 spines) and in the dendrite (top traces). Middle traces, $\mathrm{Na}^{+}$ transients in three single passive spines. Bottom traces, $\mathrm{Na}^{+}$transients in three single active spines. Data points of single spine traces were binned by a factor of 2 to improve the signal-to-noise ratio. Right, The recovery of dendritic $\mathrm{Na}^{+}$transients and passive spines could be fitted by a monoexponential decay with similar time constants $(\tau)$. Recovery in active spines followed a biexponential time course $\left(\tau_{\mathrm{f}}\right.$, fast decay constant; $\tau_{\mathrm{s}}$, slow decay time constant). The spine traces on the right represent averages of the single spine traces depicted on the left. $d$, Histogram of peak $\mathrm{Na}^{+}$transients of all spines. Individual data were pooled in steps of $2.5 \mathrm{mM} \mathrm{Na}^{+}$. The data were fitted by two Gaussian functions revealing a bimodal distribution. $e$, Top, Mean amplitudes \pm SEM of activity-induced $\mathrm{Na}^{+}$increases in dendrites and spines. The amplitude in active spines was significantly higher than those in passive spines and dendrites. Bottom, Mean decay time constants $(\tau) \pm$ SEM of activity-induced $\mathrm{Na}^{+}$increases. The fast time constant $\left(\tau_{\mathrm{f}}\right)$ of active spines was significantly different from the slow time constant $\left(\tau_{\mathrm{s}}\right)$. Arrowheads in $c$ indicate the time of synaptic stimulation.

changes ( $\sim 35 \mathrm{~mm}$ in spines), the dye will act as a buffer for $\mathrm{Na}^{+}$ and might alter $\mathrm{Na}^{+}$dynamics in spines and dendrites, as has a

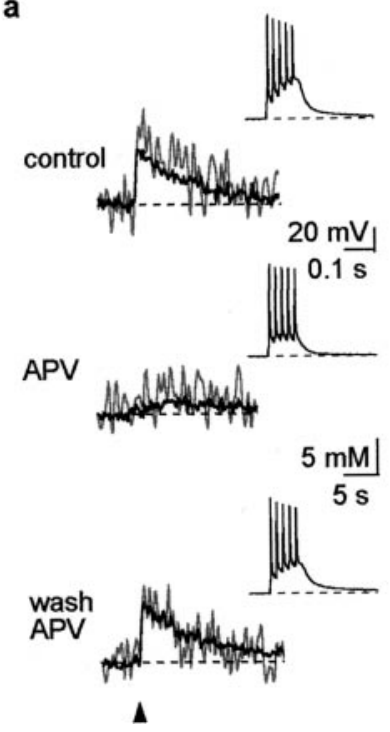

b
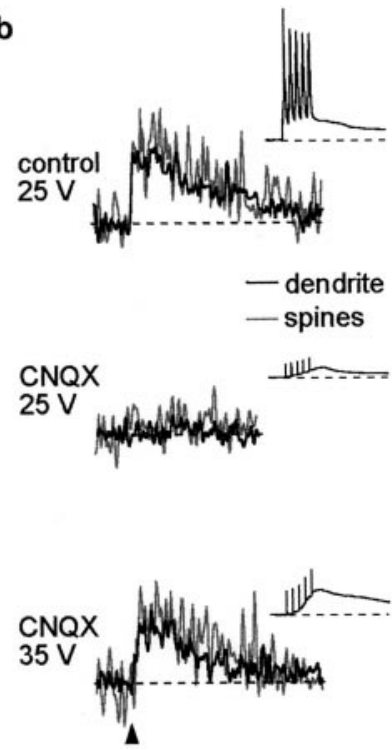

Figure 4. NMDA dependence of synaptically induced $\mathrm{Na}^{+}$transients. $a$, Blocking glutamate receptors of the NMDA type with APV strongly reduced the stimulus-induced $\mathrm{Na}^{+}$transient in the spines and the dendrite. $b, \mathrm{CNQX}$, a blocker of non-NMDA receptors, blocked activityinduced $\mathrm{Na}^{+}$transients. Increasing the stimulus intensity restored the $\mathrm{Na}^{+}$transients. $a$, CA1 pyramidal neuron; $b$, dentate gyrus granule cell. Arrowheads in $a$ and $b$ indicate the time of synaptic stimulation. Calibration for $b$ is shown in $a$; distance from the cell body in $a=120 \mu \mathrm{m}$; in $b=$ $80 \mu \mathrm{m}$.

been reported for $\mathrm{Ca}^{2+}$ signals measured with fluorometric $\mathrm{Ca}^{2+}$ indicators (Helmchen et al., 1996). Finally, decay times of $\mathrm{Na}^{+}$ transients are dependent on temperature. In an earlier study, we showed that increasing the bath temperature from 23 to $33^{\circ} \mathrm{C}$ decreased the dendritic decay constant of action potentialinduced $\mathrm{Na}^{+}$transients by a factor of 1.7 , indicating that $\mathrm{Na}^{+} /$ $\mathrm{K}^{+}$-ATPase activity plays a dominant role in restoring the electrochemical $\mathrm{Na}^{+}$gradient (Rose et al., 1999).

\section{NMDA receptor dependence}

To further analyze the mechanism of activity-induced $\mathrm{Na}^{+}$transients, we studied the contribution of ionotropic glutamate receptors. In these and all subsequent experiments (except for those illustrated in Fig. 7a,b), fluorescence signals from all spines of a given dendrite were averaged. This resulted in average spine $\mathrm{Na}^{+}$ transients that were slightly larger than those of the parent dendrites (compare Figs. 3c, 4-6, 7c).

Blocking of glutamate receptors of the NMDA type with APV resulted in a reversible reduction of the stimulus-induced $\mathrm{Na}^{+}$ transients by $\sim 80 \%$ in spines and dendrites, although the stimulation still elicited action potentials (Figs. $4 a, 5 c)(n=6)$. During perfusion with CNQX $(10 \mu \mathrm{M})$, a blocker of non-NMDA receptors, the stimulation failed to elicit action potentials, and the activity-induced $\mathrm{Na}^{+}$transient was reduced by $\sim 93 \%$ (Figs. $4 b$, $5 c)(n=4)$. Increasing the stimulus intensity caused a pronounced depolarization and restored the $\mathrm{Na}^{+}$transient (Fig. 4b) $(n=2)$. This was most likely caused by an efficient removal of the $\mathrm{Mg}^{2+}$ block of NMDA receptor channels at the site of synaptic input.

$\mathrm{Na}^{+}$transients induced by suprathreshold stimulation were suppressed by $>77 \%$ during voltage clamp. Removing extracellular $\mathrm{Mg}^{2+}$ relieved this voltage dependence and resulted in the expected augmentation of the amplitude of the $\mathrm{Na}^{+}$increase to 
a
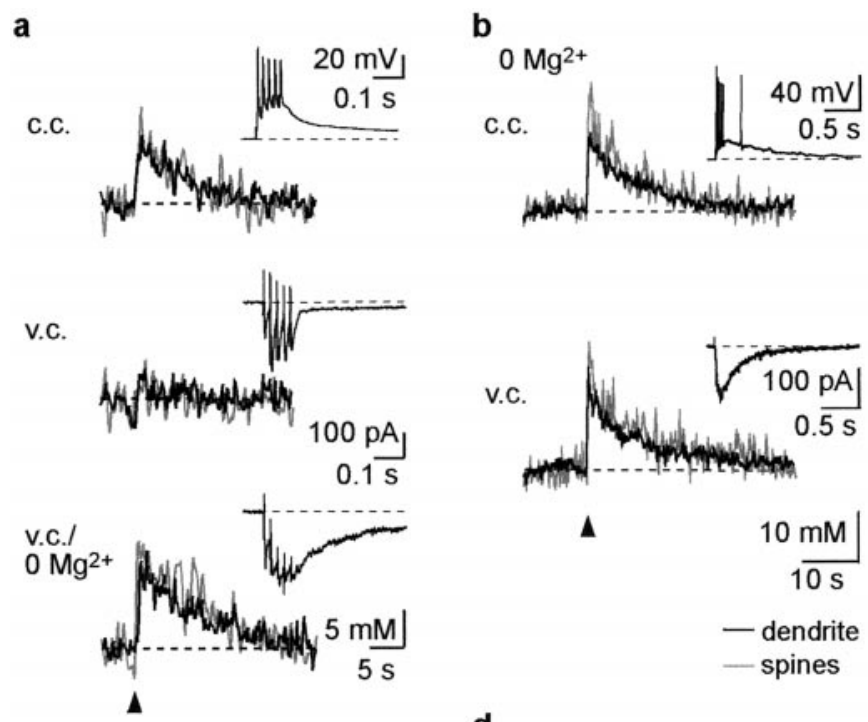

C

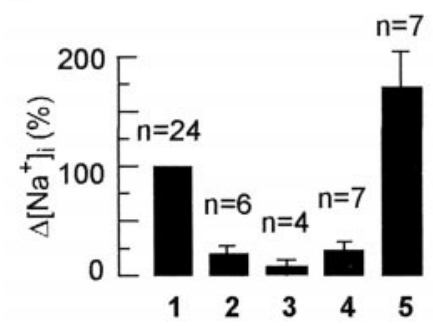

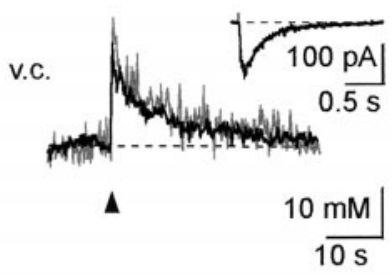

- dendrite

d

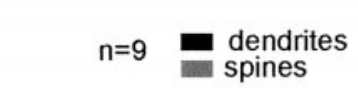

Figure 5. Membrane potential dependence of $\mathrm{Na}^{+}$transients. $a, \mathrm{Na}^{+}$ transients induced by suprathreshold stimulation were suppressed when cells were held in the voltage-clamp mode. Removing extracellular $\mathrm{Mg}^{2+}$ relieved this voltage dependence. $b$, In the absence of extracellular $\mathrm{Mg}^{2+}$, the amplitudes of the $\mathrm{Na}^{+}$transients were similar when the cells were held in the current-clamp and voltage-clamp mode. $c$, Normalized mean amplitudes of dendritic activity-induced $\mathrm{Na}^{+}$transients \pm SEM in control conditions (1), during perfusion with APV (2), CNQX (3), during voltage clamp (4), and during voltage clamp in $0 \mathrm{Mg}^{2+}$ (5). $d$, Normalized mean amplitudes of activity-induced $\mathrm{Na}^{+}$transients \pm SEM during current clamp and voltage clamp. $a, b$, Dentate gyrus granule cells; distance from the cell body in $a=60 \mu \mathrm{m}$; in $b=90 \mu \mathrm{m}$. Arrowheads in $a$ and $b$ indicate the time of synaptic stimulation.

$\sim 172 \%$ of control levels (Fig. $5 a, c)(n=7)$. In the absence of extracellular $\mathrm{Mg}^{2+}$, the amplitudes of the $\mathrm{Na}^{+}$transients were undistinguishable between stimulations performed when cells were held in the current-clamp mode (allowing the generation of action potentials) compared with those in the voltage-clamp mode (Fig. $5 b, d)(n=9)$. This demonstrates that the influx of $\mathrm{Na}^{+}$ through voltage-gated $\mathrm{Na}^{+}$channels during backpropagating action potentials does not significantly contribute to the observed $\mathrm{Na}^{+}$transients, even during concomitant synaptic activation of NMDA receptors.

These results indicate that the observed postsynaptic $\mathrm{Na}^{+}$ transients are largely mediated by $\mathrm{Na}^{+}$entry through NMDA receptor channels, whereas $\mathrm{Na}^{+}$entry through AMPA receptor channels or voltage-gated $\mathrm{Na}^{+}$channels plays only a minor role. Indeed, because of the considerably longer time course of synaptic NMDA receptor currents (Spruston et al., 1995a), $\mathrm{Na}^{+}$influx through these NMDA channels will be larger by far than that through AMPA-gated channels.

To further quantify the $\mathrm{Na}^{+}$influx through NMDA receptors, we performed experiments in which cells were held in the

a

$\mathrm{OMg}^{2+} / \mathrm{CNQX}$
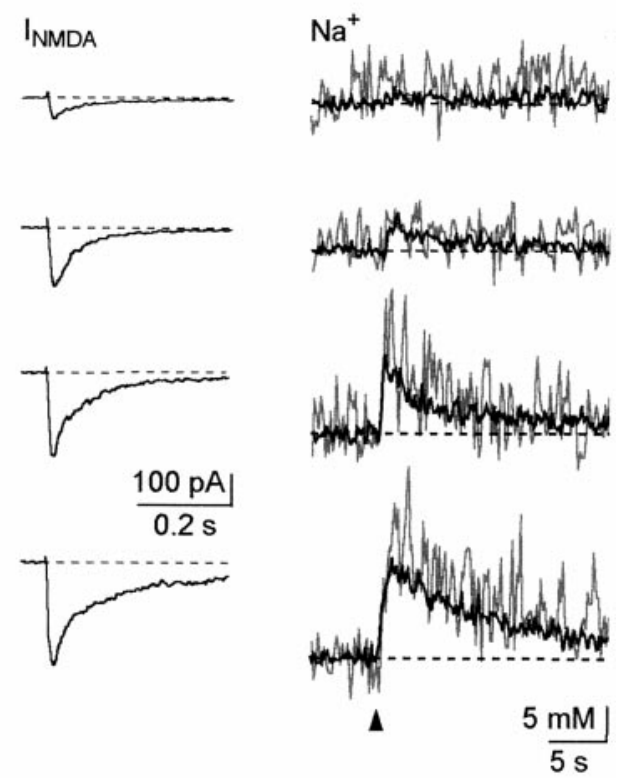

b

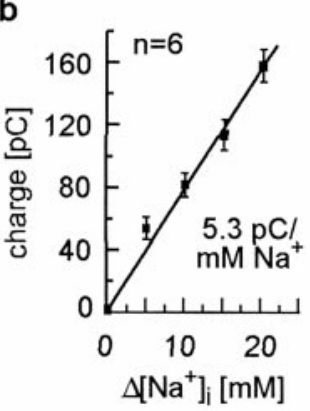

C

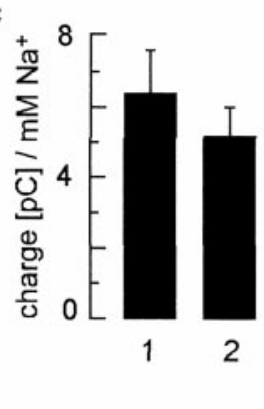

Figure 6. Correlation between charge and $\mathrm{Na}^{+}$increase. $a$, Membrane currents $\left(I_{\mathrm{NMDA}}\right)$ and corresponding $\mathrm{Na}^{+}$transients at four different increasing stimulation intensities. Experiments were performed in the voltage-clamp mode in the absence of extracellular $\mathrm{Mg}^{2+}$ and in the presence of CNQX. $b$, Plot of the mean values \pm SEM of six experiments. Individual data points were pooled in steps of $5 \mathrm{~mm} \mathrm{Na}^{+}$. The mean values follow a linear regression line $(r=0.994)$ with a slope of $5.3 \mathrm{pC} / \mathrm{mm}$ $\mathrm{Na}^{+} . c$, Histogram of mean values \pm SEM for measured charge per millimolar $\mathrm{Na}^{+}$for experiments in which no CNQX was present (1; compare Fig. 5a) and for experiments in which CNQX was added to the saline (2). Experiments were performed in dentate gyrus granule cells; distance from the cell body in $a=100 \mu \mathrm{m}$.

voltage-clamp mode in the absence of extracellular $\mathrm{Mg}^{2+}$ and in the presence of CNQX, and the stimulation intensity was increased stepwise (Fig. $6 a)(n=6)$. We then plotted the measured charge against the corresponding $\mathrm{Na}^{+}$increase and found a linear correlation with a slope of $5.3 \mathrm{pC} / \mathrm{mm} \mathrm{Na}^{+}$(Fig. 6b,c). This result corresponds closely to the prediction because the influx of $1 \mathrm{mM} \mathrm{Na}^{+}$into a given dendrite with a length of $20 \mu \mathrm{m}$ and a diameter of $2 \mu \mathrm{m}$ will result theoretically in a loss of $6 \mathrm{pC}$ negative charge.

In the voltage-clamp experiments performed in the presence of CNQX (see above), the correlation between charge and $\left[\mathrm{Na}^{+}\right]$ increase was not significantly different from the experiments performed with no CNQX added (Figs. 5a, third row, $6 c$ ). This control experiment clearly confirms that the influx of $\mathrm{Na}^{+}$ through AMPA-gated channels does not contribute significantly to the measured, synaptically induced $\mathrm{Na}^{+}$transients. 


\section{$\mathrm{Na}^{+}$transients during an LTP induction protocol}

Repetitive activation of excitatory synapses in the hippocampus causes a long-lasting increase in synaptic strength called LTP that is considered to be a cellular model for learning and memory (Bliss and Collingridge, 1993; Malenka, 1994). Usually, LTP is induced by a tetanic synaptic stimulation using stimulation frequencies of $100 \mathrm{~Hz}$ for $1 \mathrm{sec}$. The critical trigger for LTP is a rise in intracellular $\mathrm{Ca}^{2+}$ after NMDA receptor channel opening (Malenka, 1994).

To analyze $\mathrm{Na}^{+}$changes during a typical LTP induction protocol, we performed a synaptic stimulation at $100 \mathrm{~Hz}$ for $1 \mathrm{sec}$ while measuring $\mathrm{Na}^{+}$transients in dendrites and spines of CA1 pyramidal neurons. In these experiments, the calcium chelator BAPTA (10 mM) was added to the pipette solution to prevent postsynaptic $\mathrm{Ca}^{2+}$ accumulation and LTP induction. As illustrated in Figure 7, $a$ and $b$, the $\mathrm{Na}^{+}$concentration increased by $44.6 \pm 4.2 \mathrm{~mm}(n=7)$ in dendrites during the tetanus. Again (compare Fig. 3), two classes of spines could be distinguished. Although $\mathrm{Na}^{+}$transients in passive spines were similar to those measured in the dendrite, $\mathrm{Na}^{+}$increased to values of $>100 \mathrm{~mm}$ in active spines. These results demonstrate that tetanic stimulation causes enormous postsynaptic $\mathrm{Na}^{+}$transients, which may play a role in the induction process of LTP. Furthermore, during a short period (1-2 sec), the driving force for $\mathrm{Na}^{+}$will break down and synaptic transmission will collapse. It is important to note that $\mathrm{Na}^{+}$entry through cation channels activated by metabotropic glutamate receptors may partially contribute to the $\mathrm{Na}^{+}$transients during this prolonged stimulation (Congar et al., 1997).

\section{$\mathrm{Na}^{+}$transients during coincident presynaptic and postsynaptic activity}

$\mathrm{Na}^{+}$spikes actively invade dendrites of hippocampal pyramidal cells (Jaffe et al., 1992; Spruston et al., 1995b), and the coincidence of presynaptic and postsynaptic activity can lead to supralinear increases in postsynaptic $\mathrm{Ca}^{2+}$ (Magee and Johnston, 1997; Markram et al., 1997; Koester and Sakmann, 1998; Schiller et al., 1998). To analyze whether such a supralinearity also exists for postsynaptic $\mathrm{Na}^{+}$signals in dendrites and spines, we investigated the effect of coincident presynaptic and postsynaptic activity on the amplitude of synaptically induced $\mathrm{Na}^{+}$transients. Figure $7 c$ shows such an experiment. As illustrated above (compare Fig. 2), suprathreshold synaptic activation caused a prominent $\mathrm{Na}^{+}$transient, whereas subthreshold stimulation did not result in measurable $\mathrm{Na}^{+}$increases. Backpropagating APs, evoked by $2 \mathrm{msec}$ square pulse current injection at the soma at 50 $\mathrm{Hz}$, caused no or only minor $\mathrm{Na}^{+}$changes (on average $17 \%$ of control) (Fig. 7d) (cf. Rose et al., 1999). Combining backpropagating APs with subthreshold synaptic stimulation, however, resulted in a supralinear summation of $\mathrm{Na}^{+}$influx into both spines and dendrites. The pairing of presynaptic and postsynaptic activity induced $\mathrm{Na}^{+}$transients that reached $\sim 75 \%$ of those with suprathreshold stimulation (Fig. $7 d)(n=7 / 8$ cells). These results demonstrate that the occurrence of postsynaptic APs in coincidence with presynaptic activity was the critical parameter for the induction of NMDA-receptor-mediated postsynaptic $\mathrm{Na}^{+}$ transients.

\section{DISCUSSION}

\section{Local $\mathrm{Na}^{+}$transients in apical dendrites and spines}

Our results demonstrate a new and unique type of synaptically induced signal in dendrites and spines that consists of postsynaptic $\mathrm{Na}^{+}$transients. Although a direct comparison is problematic

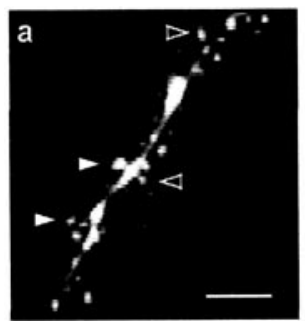

\section{C}

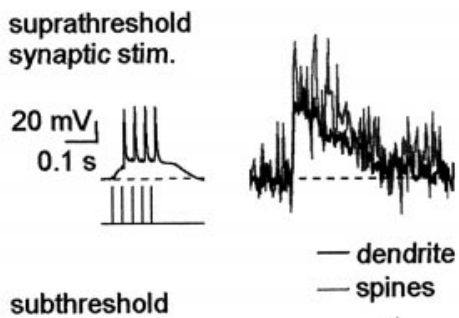

b $100 \mathrm{~Hz} / 1 \mathrm{~s}$
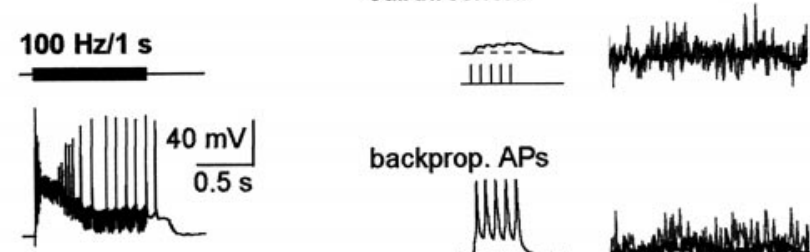

backprop. APs
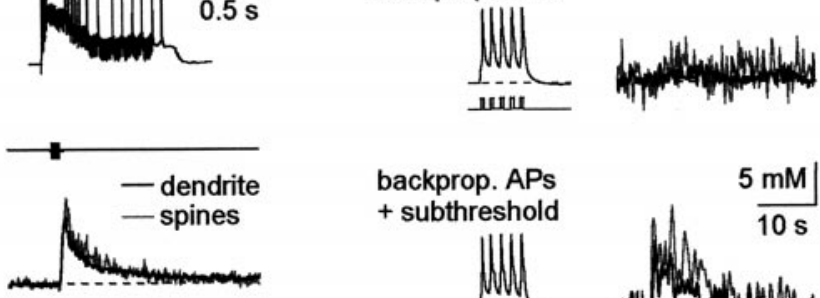

backprop. APs

+ subthreshold
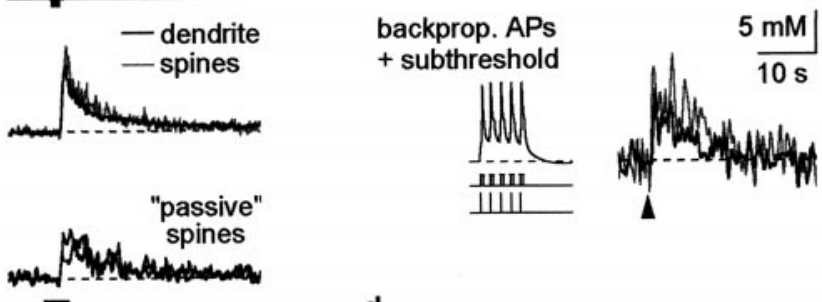

$\Delta$

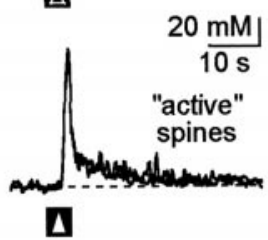

d

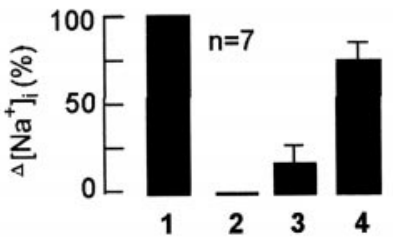

Figure 7. $\mathrm{Na}^{+}$transients during tetanic stimulation and during coincident presynaptic and postsynaptic activity in CA1 pyramidal cells. $a$, Image of the spiny dendrite chosen for the experiment depicted in $b$. Closed arrowheads indicate active spines; open arrowheads indicate passive spines from which measurements in $b$ were taken. Scale bar, $5 \mu \mathrm{m} . b$, Top, Membrane potential change induced by synaptic stimulation at $100 \mathrm{~Hz} / 1$ sec. Bottom, Average $\mathrm{Na}^{+}$transients in 16 spines and in the dendrite induced by the tetanic stimulation; $\mathrm{Na}^{+}$transients in two single passive spines; and $\mathrm{Na}^{+}$transients in two single active spines. Data points of single spine traces were binned by a factor of 2 to improve the signal-tonoise ratio. $c$, Effect of coincident presynaptic and postsynaptic activity on the amplitude of synaptically induced $\mathrm{Na}^{+}$transients. Suprathreshold synaptic activation caused $\mathrm{Na}^{+}$transients in both dendrite and adjacent spines, whereas subthreshold stimulation did not result in measurable $\mathrm{Na}^{+}$increases. Backpropagating APs evoked only minor $\mathrm{Na}^{+}$changes. Combining backpropagating APs with subthreshold synaptic stimulation, however, resulted in a supralinear summation of $\mathrm{Na}^{+}$transients of both spines and dendrites. $d$, Histogram comparing the normalized mean amplitudes \pm SEM of activity-induced $\mathrm{Na}^{+}$transients during suprathreshold stimulation (1), subthreshold stimulation (2), backpropagating APs (3), and pairing of backpropagating APs with subthreshold stimulation (4). The arrowheads in $b$ and $c$ indicate the time of synaptic stimulation; distance from the cell body in $a=150 \mu \mathrm{m}$; in $c=250 \mu \mathrm{m}$.

because spatial and temporal characteristics of measured ion changes depend on the binding characteristics of the indicator used (Helmchen et al., 1996), the $\mathrm{Na}^{+}$signals appear to differ in several ways from postsynaptic $\mathrm{Ca}^{2+}$ signals reported earlier. First, suprathreshold stimulation protocols evoke widespread elevations in $\mathrm{Ca}^{2+}$ because of influx of $\mathrm{Ca}^{2+}$ through voltage-gated $\mathrm{Ca}^{2+}$ channels activated by backpropagating action potentials (Jaffe et al., 1992; Markram et al., 1995; Spruston et al., 1995b; 
Yuste and Denk, 1995). $\mathrm{Na}^{+}$transients elicited by suprathreshold stimulation seem to be more restricted to defined dendritic regions directly at and adjacent to the stimulation site. As reported earlier (Rose et al., 1999), influx of $\mathrm{Na}^{+}$via voltage-gated $\mathrm{Na}^{+}$ channels during short trains of backpropagating action potentials causes only minor $\mathrm{Na}^{+}$increases throughout the dendritic tree.

Second, postsynaptic $\mathrm{Na}^{+}$signals in spines as well as in dendrites were observed only with suprathreshold stimulation, whereas already single, subthreshold stimuli induce $\mathrm{Ca}^{2+}$ signals in spines (Denk et al., 1995; Eilers et al., 1995, Yuste and Denk, 1995, Koester and Sakmann, 1998; Schiller et al., 1998). The absence of subthreshold $\mathrm{Na}^{+}$signals in spines might be related to the fact that these signals were too small to be detected with our technique. In any case, this result indicates that $\mathrm{Na}^{+}$accumulations in active spines during subthreshold stimulation are probably negligible $(<5 \mathrm{~mm})$ in comparison with those evoked by suprathreshold stimulation $(30-40 \mathrm{~mm})$.

Third, our results strongly suggest that the dominating pathways for $\mathrm{Na}^{+}$entry during suprathreshold synaptic activation are NMDA receptor channels. Postsynaptic $\mathrm{Ca}^{2+}$ signals, in contrast, can be mediated by several mechanisms: influx through NMDA receptor channels, influx through voltage-gated $\mathrm{Ca}^{2+}$ channels, and release from intracellular stores (Markram and Sakmann, 1994; Denk et al., 1995; Nakamura et al., 1999; Yuste et al., 1999; Kovalchuk et al., 2000; Schiller et al., 2000).

Our ability to detect large $\mathrm{Na}^{+}$gradients between active spines and the adjacent dendrite with our relatively low image-sampling frequency (4-8 Hz) was surprising. The existence of such gradients that were maintained over hundreds of milliseconds suggests the existence of a diffusion barrier or a buffer system, or both, for $\mathrm{Na}^{+}$in the spines. The apparent diffusion coefficient for free $\mathrm{Na}^{+}$is $\sim 13 \times 10^{-6} \mathrm{~cm}^{2} / \mathrm{sec}$ (Push and Neher, 1988) and about twice that value for SBFI-bound $\mathrm{Na}^{+}$[assuming that the diff usion coefficient is similar to that of fura-2 (Push and Neher, 1988)]. Unrestricted equilibration of $\mathrm{Na}^{+}$and SBFI-bound $\mathrm{Na}^{+}$between distances of $\sim 1 \mu \mathrm{m}$ will be accomplished, therefore, within milliseconds. Because diffusion from spines to the adjacent dendrite is slowed by a factor of $10-100$ by the spine neck (Svoboda et al., 1996), $\mathrm{Na}^{+}$gradients between spine and adjacent dendrites should be largely equilibrated within $\sim 100 \mathrm{msec}$.

Significant gradients between spines and the adjacent dendritic shaft have also been reported for $\mathrm{Ca}^{2+}$ signals (Jaffe and Brown, 1997; Yuste et al., 1999; Kovalchuk et al., 2000; Majewska et al., 2000), suggesting that spines may be chemically isolated from dendrites. In addition to the diffusion barrier caused by spine necks, calcium pumps or other $\mathrm{Ca}^{2+}$ uptake systems and $\mathrm{Ca}^{2+}$ buffers might be responsible for the observed biochemical isolation of spines (Koch and Zador, 1993; Maeda et al., 1999). Similarly one could speculate about a high presence of $\mathrm{Na}^{+}$ pumps $\left(\mathrm{Na}^{+}-\mathrm{K}^{+}-\right.$ATPase $)$in spine necks that might account for the compartmentalization in $\mathrm{Na}^{+}$. Alternatively, the spine head may contain molecules that bind and buffer $\mathrm{Na}^{+}$.

\section{Functional implications of postsynaptic $\mathrm{Na}^{+}$transients}

The NMDA receptor channels are widely accepted as coincident detectors of presynaptic and postsynaptic activity (Malenka, 1994). They were shown to mediate a supralinear increase in postsynaptic $\mathrm{Ca}^{2+}$ signals during pairing of an action potential with synaptic stimulation (Yuste and Denk, 1995; Magee and Johnston, 1997; Markram et al., 1997; Koester and Sakmann, 1998; Schiller et al., 1998). Our results indicate that NMDA receptor activity might be involved in yet another signal for coincidence detection, which consists of $\mathrm{Na}^{+}$transients. Postsynaptic $\mathrm{Na}^{+}$transients seem to be ideally suited for coincidence detection because they are restricted to the site of activation and exhibit all-or-none characteristics in that they require the occurrence of postsynaptic APs in coincidence with presynaptic activity.

Although the direct physiological role of $\mathrm{Na}^{+}$accumulations in spines is unclear, it is firmly established that the inwardly directed $\mathrm{Na}^{+}$gradient regulates many cellular processes, among them intracellular $\mathrm{Ca}^{2+}$ homeostasis via $\mathrm{Na}^{+} / \mathrm{Ca}^{2+}$ exchange (Blaustein and Lederer, 1999). In presynaptic terminals of cultured hippocampal cells, an elevation of $\mathrm{Na}^{+}$was accompanied by an increase in $\mathrm{Ca}^{2+}$, causing enhanced transmitter release (Bouron and Reuter, 1996). A reduction in the $\mathrm{Na}^{+}$gradient slowed $\mathrm{Ca}^{2+}$ extrusion in cerebellar neurons (Kiedrowski et al., 1994; Fierro et al., 1998). In granule cell presynaptic terminals, $\mathrm{Ca}^{2+}$ extrusion via the $\mathrm{Na}^{+} / \mathrm{Ca}^{2+}$ exchange leads to $\mathrm{Na}^{+}$accumulation (Regehr, 1997). These studies indicate that $\mathrm{Na}^{+}$accumulations in spines might shape the time course of postsynaptic $\mathrm{Ca}^{2+}$ transients and vice versa. Therefore, activation of $\mathrm{Na}^{+} /$ $\mathrm{Ca}^{2+}$ exchange also might contribute partly to the synaptically induced $\mathrm{Na}^{+}$transients observed in our study. The $\mathrm{Na}^{+}$changes measured during tetanic stimulation in the presence of $10 \mathrm{~mm}$ BAPTA, however, indicate that considerable $\mathrm{Na}^{+}$increases also occur without a contribution of $\mathrm{Na}^{+} / \mathrm{Ca}^{2+}$ exchange. Furthermore, a rise in postsynaptic $\mathrm{Na}^{+}$will slow the $\mathrm{Na}^{+}$-dependent uptake of glutamate or may even lead to its reversal and therefore could influence excitatory transmission (Attwell et al., 1993).

Another emerging possibility is that increases in $\mathrm{Na}^{+}$concentration might induce synaptic plasticity by selectively increasing the open probability of NMDA receptors, a process that is controlled by a channel-associated Src kinase ( $\mathrm{Yu}$ and Salter, 1998). This mechanism might be especially powerful during more intensive stimulation protocols and could be important in the Src-dependent induction of LTP in CA1 hippocampal neurons (Lu et al., 1998). Thus, synaptically induced NMDA-dependent $\mathrm{Na}^{+}$accumulations in spines might provide an efficient mechanism of autoregulation of NMDA conductance and input-specific strengthening of active synapses. It is important to note that in isolated patch recordings, $\left[\mathrm{Na}^{+}\right]$elevations by $30-40 \mathrm{~mm}$ were sufficient to upregulate the NMDA receptor function ( $\mathrm{Yu}$ and Salter, 1998). Under our conditions of stimulation with an LTPinducing protocol, we saw $\mathrm{Na}^{+}$peak levels of $>100 \mathrm{~mm}$ in active spines.

Finally, an important possibility that must be considered is that increases in intracellular $\mathrm{Na}^{+}$will reduce the driving force for glutamatergic currents. At rest, the reversal potential of AMPA and NMDA receptor-mediated currents is close to $0 \mathrm{mV}$. Short synaptic bursts will briefly reduce their reversal potential to approximately $-35 \mathrm{mV}$ [calculation based on assumed peak intracellular concentrations of $35 \mathrm{mM} \mathrm{Na}^{+}$(see Results) and 130 $\mathrm{mM} \mathrm{K}^{+}$, and extracellular concentrations of $145 \mathrm{mM} \mathrm{Na}^{+}$and 8 $\mathrm{mM} \mathrm{K}^{+}$; see Materials and Methods and Dietzel and Heinemann (1985)]. At this potential, NMDA receptor currents are already significantly reduced because of voltage-dependent block by $\mathrm{Mg}^{2+}$ (Spruston et al., 1995a). With more intense synaptic activity and larger ion changes, the reversal potential for glutamatergic currents will be even more negative, which would eventually result in dendritic saturation (Sejnowski and Qian, 1992; Bush and Sejnowski, 1994). Glutamatergic currents will be largely diminished, thereby protecting the postsynaptic input sites from excessive accumulations of $\mathrm{Na}^{+}$and $\mathrm{Ca}^{2+}$, which have been 
implicated in inducing cellular excitotoxicity (Lee et al., 1999). This intriguing prediction, however, will probably be difficult to test experimentally at present, because peak ionic changes persist for only very short periods (Fig. 7). Nevertheless, it seems reasonable to speculate that dendritic saturation caused by increases in postsynaptic $\mathrm{Na}^{+}$levels during excitatory synaptic transmission could play an important role in the input-specific protection of overexcitation of synapses. The development of specific $\mathrm{Na}^{+}$ chelators that are effective in the range of tens of millimolar will help to test this hypothesis.

\section{REFERENCES}

Attwell D, Barbour B, Szatkowski M (1993) Nonvesicular release of neurotransmitter. Neuron 11:401-407.

Blaustein MP, Lederer WJ (1999) Sodium/calcium exchange: its physiological implications. Physiol Rev 79:763-854.

Bliss TVP, Collingridge GL (1993) A synaptic model of memory: longterm potentiation in the hippocampus. Nature 361:31-39.

Bouron A, Reuter H (1996) A role of intracellular $\mathrm{Na}^{+}$in the regulation of synaptic transmission and the turnover of the vesicular pool in cultured hippocampal cells. Neuron 17:969-978.

Bush PC, Sejnowski TJ (1994) Effects of inhibition and dendritic saturation in simulated neocortical pyramidal cells. J Neurophysiol 71:2183-2193.

Callaway JC, Ross WN (1997) Spatial distribution of synaptically activated sodium concentration changes in cerebellar Purkinje neurons. J Neurophysiol 77:145-152.

Congar P, Leinekugel X, Ben-Ari Y, Crepel V (1997) A long-lasting calcium-activated nonselective cationic current is generated by synaptic stimulation or exogenous activation of group I metabotropic glutamate receptors in CA1 pyramidal neurons. J Neurosci 17:5366-5379.

Denk W, Strickler JH, Webb WW (1990) Two-photon laser scanning fluorescence microscopy. Science 248:73-76.

Denk W, Sugimori M, Llinas R (1995) Two types of calcium response limited to single spines in cerebellar Purkinje cells. Proc Natl Acad Sci USA 92:8279-8282.

Denk W, Yuste R, Svoboda K, Tank DW (1996) Imaging calcium dynamics in dendritic spines. Curr Opin Neurobiol 6:372-378.

Dietzel I, Heinemann U (1985) Dynamic variations of the brain cell microenvironment in relation to neuronal hyperactivity. Ann NY Acad Sci 481:72-86.

Edwards FA, Konnerth A, Sakmann B, Takahashi T (1989) A thin slice preparation for patch-clamp recordings from neurones of the mammalian central nervous system. Pflügers Arch 414:600-612.

Eilers J, Konnerth A (1997) Dendritic signal integration. Curr Opin Neurobiol 7:385-390.

Eilers J, Augustine GJ, Konnerth A (1995) Subthreshold synaptic $\mathrm{Ca}^{2+}$ signalling in fine dendrites and spines of cerebellar Purkinje neurons. Nature 373:155-158.

Fierro L, DiPolo R, Llano I (1998) Intracellular calcium clearance in Purkinje cell somata from rat cerebellar slices. J Physiol (Lond) 510:499-512.

Harris KM (1999) Structure, development, and plasticity of dendritic spines. Curr Opin Neurobiol 9:343-348.

Harris KM, Kater SB (1994) Dendritic spines: cellular specializations imparting both stability and flexibility to synaptic function. Annu Rev Neurosci 17:341-371.

Helmchen F, Imoto K, Sakmann B (1996) $\mathrm{Ca}^{2+}$ buffering and action potential-evoked $\mathrm{Ca}^{2+}$ signaling in dendrites of pyramidal neurons. Biophys J 70:1069-1081.

Jaffe DB, Brown TH (1997) Calcium dynamics in thorny excrescences of CA3 pyramidal neurons. J Neurophysiol 78:10-18.

Jaffe DB, Johnston D, Lasser-Ross N, Lisman JE, Miyakawa H, Ross WN (1992) The spread of $\mathrm{Na}^{+}$spikes determines the pattern of dendritic $\mathrm{Ca}^{2+}$ entry into hippocampal neurons. Nature 357:244-246.

Kiedrowski L, Brooker G, Costa E, Wroblewski JT (1994) Glutamate impairs neuronal calcium extrusion while reducing sodium gradient. Neuron 12:295-300.

Koch C, Zador A (1993) The function of dendritic spines: devices subserving biochemical rather than electrical compartmentalization. J Neurosci 13:413-422.

Koester HJ, Sakmann B (1998) Calcium dynamics in single spines during coincident pre- and postsynaptic activity depend on relative timing of back-propagating action potentials and subthreshold excitatory postsynaptic potentials. Proc Natl Acad Sci USA 95:9596-9601.

Kovalchuk Y, Eilers J, Lisman J, Konnerth A (2000) NMDA receptormediated subthreshold $\mathrm{Ca}^{2+}$ signals in spines of hippocampal neurons. J Neurosci 20:1791-1799.

Lasser-Ross N, Ross WN (1992) Imaging voltage and synaptically activated sodium transients in cerebellar Purkinje cells. Proc R Soc Lond B Biol Sci 247:35-39.
Lee JM, Zipfel GJ, Choi DW (1999) The changing landscape of ischaemic brain injury mechanisms. Nature 399[Suppl]:A7-A14.

Linden DJ, Smeyne M, Connor JA (1993) Induction of cerebellar longterm depression in culture requires postsynaptic action of sodium ions. Neuron 11:1093-1100.

Lisman JE (1997) Bursts as a unit of neural information: making unreliable synapses reliable. Trends Neurosci 20:38-43.

Lu YM, Roder JC, Davidow J, Salter MW (1998) Src activation in the induction of long-term, potentiation in CA1 hippocampal neurons. Science 279:1363-1367.

Maeda H, Ellis-Davies G, Ito K, Miyashita Y, Kasai H (1999) Supralinear $\mathrm{Ca}^{2+}$ signaling by cooperative and mobile $\mathrm{Ca}^{2+}$ buffering in Purkinje neurons. Neuron 24:989-1002.

Magee JC, Johnston D (1997) A synaptically controlled, associative signal for Hebbian plasticity in hippocampal neurons. Science 275:209-213.

Majewska A, Brown E, Ross J, Yuste R (2000) Mechanisms of calcium decay kinetics in hippocampal spines: role of spine calcium pumps and calcium diffusion through the spine neck in biochemical compartmentalization. J Neurosci 205:1722-1734.

Malenka RC (1994) Synaptic plasticity in the hippocampus: LTP and LTD. Cell 78:535-538.

Markram H, Sakmann B (1994) Calcium transients in dendrites of neocortical neurons evoked by single subthreshold excitatory postsynaptic potentials via low-voltage-activated calcium channels. Proc Natl Acad Sci USA 91:5207-5211

Markram H, Helm PJ, Sakmann B (1995) Dendritic calcium transients evoked by single back-propagating action potentials in rat neocortical pyramidal neurons. J Physiol (Lond) 485:1-20.

Markram H, Lubke J, Frotscher M, Sakmann B (1997) Regulation of synaptic efficacy by coincidence of postsynaptic APs and EPSPs. Science 275:213-215.

Miyakawa H, Ross WN, Jaffe D, Callaway JC, Lasser-Ross N, Lisman JE, Johnston D (1992) Synaptically activated increases in $\mathrm{Ca}^{2+}$ concentration in hippocampal CA1 pyramidal cells are primarily due to voltage-gated $\mathrm{Ca}^{2+}$ channels. Neuron 9:1163-1173.

Nakamura T, Barbara JG, Nakamura K, Ross W (1999) Synergistic release of $\mathrm{Ca}^{2+}$ from $\mathrm{IP}_{3}$-sensitive stores evoked by synaptic activation of mGluRs paired with backpropagating action potentials. Neuron 24:727-737.

Otto T, Eichenbaum H, Wiener SI, Wible CG (1991) Learning-related patterns of CA1 spike trains parallel stimulation parameters optimal for inducing hippocampal long-term potentiation. Hippocampus 1:181-192.

Push M, Neher E (1988) Rates of diffusional exchange between small cells and a measuring patch pipette. Pflügers Arch 411:204-211.

Regehr W (1997) Interplay between sodium and calcium dynamics in granule cell presynaptic terminals. Biophys J 73:2476-2488.

Rose CR, Ransom BR (1997) Regulation of intracellular sodium in cultured rat hippocampal neurones. J Physiol (Lond) 499:573-587.

Rose CR, Kovalchuk Y, Eilers J, Konnerth A (1999) Two-photon $\mathrm{Na}^{+}$ imaging in spines and fine dendrites of central neurons. Pflügers Arch 439:201-207.

Schiller J, Schiller Y, Clapham DE (1998) NMDA receptors amplify calcium influx into dendritic spines during associative pre- and postsynaptic activation. Nat Neurosci 1:114-118.

Schiller J, Major G, Koester HJ, Schiller Y (2000) NMDA spikes in basal dendrites of cortical pyramidal neurons. Nature 404:285-289.

Segal M, Korkotian E, Murphy DD (2000) Dendritic spine formation and pruning: common cellular mechanisms? Trends Neurosci 23:53-57.

Sejnowski TJ, Qian N (1992) Synaptic integration by electrodiffusion in dendritic spines. In: Single neuron computation (McKenna T, Davis J, Zornetzer SF, eds), pp 117-139. Boston: Academic.

Spruston N, Jonas P, Sakmann B (1995a) Dendritic glutamate receptor channels in rat hippocampal CA3 and CA1 pyramidal neurons. J Physiol (Lond) 482:325-352.

Spruston N, Schiller Y, Stuart G, Sakmann B (1995b) Activitydependent action potential invasion and calcium influx into hippocampal CA1 dendrites. Science 268:297-300.

Stuart G, Spruston N, Sakmann B, Häusser M (1997) Action potential initiation and backpropagation in neurons of the mammalian CNS. Trends Neurosci 20:125-131.

Svoboda K, Tank DW, Denk W (1996) Direct measurement of coupling between dendritic spines and shafts. Science 272:716-719.

Yu XM, Salter MW (1998) Gain control of NMDA-receptor currents by intracellular sodium. Nature 396:469-474.

Yuste R, Denk W (1995) Dendritic spines as basic functional units of neuronal integration. Nature 375:682-684.

Yuste R, Majewska A, Cash SS, Denk W (1999) Mechanisms of calcium influx into hippocampal spines: heterogeneity among spines, coincidence detection by NMDA receptors, and optical quantal analysis. J Neurosci 19:1976-1987.

Yuste R, Majewska A, Holthoff K (2000) From form to function: calcium compartmentalization in dendritic spines. Nat Neurosci 3:653659 . 